УДК 615.07+582.688.31

DOI 10.11603/mcch.2410-681X.2019.v.i2.10294

К. М. Яцюк ${ }^{1}$, М. І. Федоровська ${ }^{1}$, С. М. Марчишин ${ }^{2}$, Л. І. Будняк², Л. В. Слободянюк ${ }^{2}$ ІВАНО-ФРАНКІВСЬКИЙ НАЦІОНАЛЬНИЙ МЕДИЧНИЙ УНІВЕРСИТЕТ ${ }^{1}$ ТЕРНОПІЛЬСЬКИЙ ДЕРЖАВНИЙ МЕДИЧНИЙ УНІВЕРСИТЕТ ІМЕНІ І. Я. ГОРБАЧЕВСЬКОГО 2

\title{
ОДЕРЖАННЯ ТА СТАНДАРТИЗАЦІЯ ЗГУЩЕНОГО СОКУ 3 ЖУРАВЛИНИ БОЛОТНОЇ ПЛОДІВ
}

Вступ. Цінною сировиною для розробки фрітопрепаратів є журавлини болотної плоди, які застосовують при лікуванні інфеекцій сечовидільної системи, застудних та стоматологічних захворювань. Біологічно активні речовини, що містяться в цій сировині, здатні проявляти антимікробні властивості щодо головних уропатогенних итамів мікроорганізмів. При розробці твердих лікарських фрорм для застосування в урології перспективним є одержання згущеного соку з журавлини болотної плодів.

Мета дослідження - розробити технологію одержання та здійснити стандартизацію згущеного соку з журавлини болотної плодів.

Методи дослідження. Свіжоодержаний та згущений сік з журавлини болотної плодів піддавали аналізу за такими показниками, як: опис, рН, сухий залишок (свіжий сік), ідентифрікація і кількісне визначення основних груп біологічно активних речовин.

Результати й обговорення. У результаті проведених досліджень розроблено оптимальну технологію одержання згущеного соку з журавлини болотної плодів. Для свіжоодержаного та згущеного соку визначено основні показники якості.

Висновки. Обірунтовано оптимальний метод одержання свіжого соку з журавлини болотної плодів та визначено такі його критерії якості, як: зовнішній вигляд, рН від 2,46 до 2,5, ідентифрікація методами тонкошарової хроматограсрії, кольоровими реакціями, кількісне визначення методами титриметрії та УФ-спектрофотометрії (органічні кислоти - не менше 0,78 \%, поліфеноли - не менше 1,8 \%, таніни - не менше 0,39 \%, проантоціанідини - не менше 0,33 \%). При одержанні згущеного соку з журавлини болотної плодів встановлено, що оптимальним методом загущування є інфррачервоне сушіння при $35-40{ }^{\circ} \mathrm{C}$ до $30 \%$ від початкової маси. Визначено основні показники якості згущеного соку з журавлини болотної плодів, а саме: опис, рН від 2,46 до 2,5, кількісний вміст (органічні кислоти - не менше 2,37 \%, поліфреноли - не менше 5,37 \%, таніни - не менше 1,06 \%, проантоціанідини - не менше 0,95 \%). Розроблено технологічну схему одержання згущеного соку з журавлини болотної плодів.

КЛЮчОВІ СЛОВА: журавлина болотна; згущений сік; біологічно активні речовини; спектрофотометрія; технологія соку.

ВСТУП. Виділення та збереження біологічно активних речовин (БАР) з лікарської рослинної сировини (ЛРС) є актуальною темою сучасних фрармацевтичних досліджень. Цінною ЛРС для розробки фітопрепаратів $€$ журавлини болотної плоди, які, завдяки корисним харчовим та лікувальним властивостям, широко використовують в офріцинальній і народній медицині для лікування інфекцій сечовидільної системи, застудних та стоматологічних захворювань [1]. Ця ЛРС містить різні групи БАР (органічні кислоти, поліфенольні речовини, проантоціанідини), які зумовлюють широкий спектр фрармакологічних ефректів [2]. Журавлини болотної плоди здатні

(с) К. М. Яцюк, М. І. Федоровська, С. М. Марчишин, Л. І. Будняк, Л. В. Слободянюк, 2019. проявляти антимікробні властивості щодо головних уропатогенних штамів мікроорганізмів [3]. Проантоціанідини забезпечують пригнічення адгезії мікроорганізмів до тканин організму, зменшуючи, таким чином, можливість біоплівкоутворення, яке розглядають як важливий чинник патологічного процесу в сечовивідних шляхах $[4,5]$. Також журавлини плоди проявляють антигелікобактерні та противірусні властивості. Вони є ефрективними антиоксидантами, які здатні пригнічувати окиснення ліпопротеїнів. Експериментально підтверджено здатність френольних сполук журавлини пригнічувати ріст культур пухлинних клітин [6].

3 огляду на вищевикладене, розробка технології одержання та стандартизація згущеного 
соку з журавлини болотної свіжих плодів і розробка лікарського засобу на його основі $€$ актуальним питанням сучасної фрармації.

Мета дослідження - розробити технологію одержання та здійснити стандартизацію згущеного соку з журавлини болотної плодів.

МЕТОДИ ДОСЛІДЖЕННЯ. Для одержання соку було використано журавлини болотної плоди (ДСТУ 5035:2008 “Журавлина свіжа. Технічні умови"), зібрані у фразу стиглості в жовтні 2018 р. на території Долинського району Івано-Франківської області.

У процесі отримання згущеного соку з журавлини болотної плодів вивчали особливості пресування свіжозібраної сировини та загущування одержаного продукту.

Свіжоодержаний та згущений сік піддавали аналізу за такими показниками, як: опис, $\mathrm{pH}$, сухий залишок (свіжий сік), ідентифікація і кількісне визначення основних груп БАР (органічні кислоти, поліфеноли, таніни, проантоціанідини).

Ідентифікацію БАР проводили за стандартними методиками: органічних кислот - методом тонкошарової хроматографрії [7], окиснювальних френолів - за допомогою кольорових реакцій, проантоціанідинів - за реакцією Bate-Smith.

Кількісний вміст поліфенолів і танінів визначали спектрофотометричним методом за загальноприйнятою методикою ДФУ 2.0 (2014р.) на спектрофоотометрі Lambda 25 Perkin Elmer (США), вміст органічних кислот - титриметричним методом за методикою ДФУ 2.1 (2016 р.), описаною в монограсрії "Шипшини плоди".

Кількісний вміст БАР визначали методом УФ-спектрофротометрії, який описано у ДФУ 2.0 пункт 2.2.25 (поліфенольні сполуки, таніни, проантоціанідини) [8], і титриметричним методом (органічні кислоти) [7].

РЕЗУЛЬТАТИЙ ОБГОВОРЕННЯ. На першОму етапі роботи обирали оптимальний метод одержання соку з журавлини болотної плодів, який би забезпечував не менше 80 \% виходу кінцевого продукту.

Для встановлення оптимального методу одержання соку використано такі технології: I відтискання соку із цільної ЛРС за допомогою механічного преса, II - відтискання попередньо подрібненої ЛРС за допомогою механічного преса, III - ручне відтискання попередньо подрібненої ЛРС та IV - відтискання за допомогою механічного преса ЛРС, яку піддавали попередньому заморожуванню (з метою руйнування міжклітинних стінок усередині сировини). Відсотковий вихід соку, одержаного різними методами, наведено в таблиці 1.

Найбільший вихід соку було одержано шляхом відтискання за допомогою механічного преса ЛРС, попередньо подрібненої кухонним електричним шнековим подрібнювачем (фрірми "Bosch").

Свіжоодержаний сік піддавали аналізу за органолептичними та фрізико-хімічними показниками (табл. 2).

Для стабільного зберігання соку та подальшого одержання твердих лікарських фрорм на його основі проводили загущування соку. 3 метою вибору оптимального методу упарювання соку здійснювали за допомогою роторного випарювача LABOROTA 400 ("Неidolph", Німеччина) при температурі водяної бані $(60 \pm 5){ }^{\circ} \mathrm{C}$ та в шафрі зразка "Індиго" з інфррачервоним випромінюванням при температурі 35-40 C. Упарювання проводили до одержання згущеного соку в кількості 1/2, 1/3, 1/4 від його початкової маси, після чого одержаний продукт, темно-червону в'язку масу зі специфічним приємним запахом, охолоджували та переносили у скляну тару для зберігання і подальшого використання. Ступінь загущування соку вибирали залежно від його здатності утворювати грануляційну масу 3 порошковою сумішшю речовин наповнювачів. Результати експерименту наведено в таблиці 3.

Отже, згідно з одержаними результатами, для утворення гранул оптимальним $€$ використання згущеного соку до 30 \% від його початкової маси.

3 метою вибору методу загущування соку визначали вміст БАР в одержаному продукті. Результати дослідження наведено в таблиці 4.

Згідно з одержаними результатами, максимальна кількість БАР зберігається у продукті, який піддавали упарюванню в інфррачервоній сушарці. Саме цей метод рекомендовано використовувати для отримання згущеного соку 3 журавлини болотної плодів.

Результати аналізу за органолептичними та фрізико-хімічними показниками згущеного соку 3 журавлини болотної плодів наведено в таблиці 5.

Таблиця 1 - Вихід соку залежно від методу одержання

\begin{tabular}{|c|c|c|c|}
\hline № методу & Кількість сировини, г & Вихід соку, мл & Вихід соку, \% \\
\hline I & 1000,0 & 736 & 73,6 \\
\hline II & 1000,0 & 800 & 80,0 \\
\hline III & 1000,0 & 762 & 76,2 \\
\hline IV & 1000,0 & 713 & 71,3 \\
\hline \multicolumn{2}{|l}{} \\
\hline
\end{tabular}


Таблиця 2 - Показники якості свіжоодержаного соку з журавлини болотної плодів

\begin{tabular}{|c|c|c|}
\hline Показник & Метод визначення & Норма \\
\hline Зовнішній вигляд & Органолептично & $\begin{array}{l}\text { Темно-червона прозора рідина зі } \\
\text { специфрічним приємним запахом }\end{array}$ \\
\hline $\mathrm{pH}$ & Потенціометрично за допомогою рН-метра & Від 2,46 до 2,5 \\
\hline Сухий залишок & Гравіметрично & Не менше 8,9 \% \\
\hline \multicolumn{3}{|c|}{ Ідентисрікація } \\
\hline Органічні кислоти & Тонкошарова хроматограсрія & Жовті плями на блакитному фроні \\
\hline $\begin{array}{l}\text { Окиснювальні феноли } \\
\text { (поліфреноли, таніни) }\end{array}$ & $\begin{array}{l}\text { Якісні реакції: } \\
\text { 1. } 3 \text { розчином ферум (III) амоній сульфрату. } \\
\text { 2. } 31 \% \text { розчином желатину. } \\
\text { 3. } 31 \% \text { розчином хініну гідрохлориду }\end{array}$ & $\begin{array}{c}\text { Темно-зелене забарвлення } \\
\text { свідчило про наявність танінів. } \\
\text { З'являлася каламуть, яка } \\
\text { зникала при надлишку желатину. } \\
\text { 3'являвся аморфний осад }\end{array}$ \\
\hline Проантоціанідини & Реакція Bates-Smith & $\begin{array}{l}\text { Утворення інтенсивного } \\
\text { червоного забарвлення }\end{array}$ \\
\hline \multicolumn{3}{|c|}{ Кількісне визначення } \\
\hline Органічні кислоти & Титриметрично & Не менше 0,78 \% \\
\hline Поліфеноли & Спектрофотометрично & Не менше 1,80 \% \\
\hline Таніни & Спектрофотометрично & Не менше 1,18 \% \\
\hline Проантоціанідини & Спектрофротометрично & Не менше 0,33 \% \\
\hline
\end{tabular}

Таблиця 3 - Оцінка якості грануляту

\begin{tabular}{|c|c|c||}
\hline Ступінь упарювання соку & Зовнішній вигляд & Характеристика грануляту \\
\hline $1 / 2(50 \%)$ & $\begin{array}{c}\text { Червона рідка маса з приємним } \\
\text { запахом, характерним для } \\
\text { журавлини болотної плодів }\end{array}$ & $\begin{array}{c}\text { При додаванні згущеного соку до } \\
\text { речовин-наповнювачів утворюєтья } \\
\text { пливка маса, що не здатна } \\
\text { утворити гранули }\end{array}$ \\
\hline $1 / 3(30 \%)$ & $\begin{array}{c}\text { Темно-червона в'язка маса зі } \\
\text { специорічним приємним запахом }\end{array}$ & $\begin{array}{c}\text { Одержано пластичну масу, з якої } \\
\text { легко утворюються гранули }\end{array}$ \\
\hline $1 / 4(25 \%)$ & Темно-червона густа в'язка \\
& маса зі специфічним приємним \\
& запахом & $\begin{array}{c}\text { При додаванні згущеного соку } \\
\text { утворюється суха маса, що } \\
\text { потребує додаткового зволоження }\end{array}$ \\
\hline \multicolumn{2}{|c}{}
\end{tabular}

Таблиця 4 - Вміст біологічно активних речовин у згущеному соку з журавлини болотної плодів, одержаному різними методами висушування

\begin{tabular}{|l|c|c|}
\hline \multicolumn{1}{|c|}{ Вміст БАР, \% } & Роторний випарювач & Інфрачервона сушарка \\
\hline Органічні кислоти & $2,56 \pm 0,02$ & $2,96 \pm 0,02$ \\
\hline Поліфенольні сполуки & $5,65 \pm 0,01$ & $6,71 \pm 0,01$ \\
\hline Таніни & $1,15 \pm 0,01$ & $1,33 \pm 0,01$ \\
\hline Проантоціанідини & $1,02 \pm 0,01$ & $1,19 \pm 0,01$ \\
\hline
\end{tabular}

Таблиця 5 - Показники якості згущеного соку з журавлини болотної плодів

\begin{tabular}{|l|c|c|}
\hline \multicolumn{1}{|c|}{ Показник } & Метод визначення & Норма \\
\hline 3овнішній вигляд & Органолептично & $\begin{array}{c}\text { Темно-червона в'язка маса зі } \\
\text { специфрічним приємним запахом }\end{array}$ \\
\hline pH & $\begin{array}{c}\text { Потенціометрично за допомогою } \\
\text { рН-метра }\end{array}$ & Від 2,46 до 2,5 \\
\hline \multicolumn{2}{|c|}{ Кількісне визначення } \\
\hline Органічні кислоти & Титриметрично & Не менше 2,37\% \\
\hline Полісреноли & Спектрофотометрично & Не менше 5,37\% \\
\hline Таніни & Спектрофотометрично & Не менше 1,06\% \\
\hline Проантоціанідини & Спектрофотометрично & Не менше 0,95\% \\
\hline
\end{tabular}

У результаті проведених досліджень встановлено оптимальний метод одержання згущеного соку з журавлини болотної плодів, що за- безпечує його максимальний вихід із сировини, та розроблено технологічну блок-схему отримання цього продукту (рис.). 


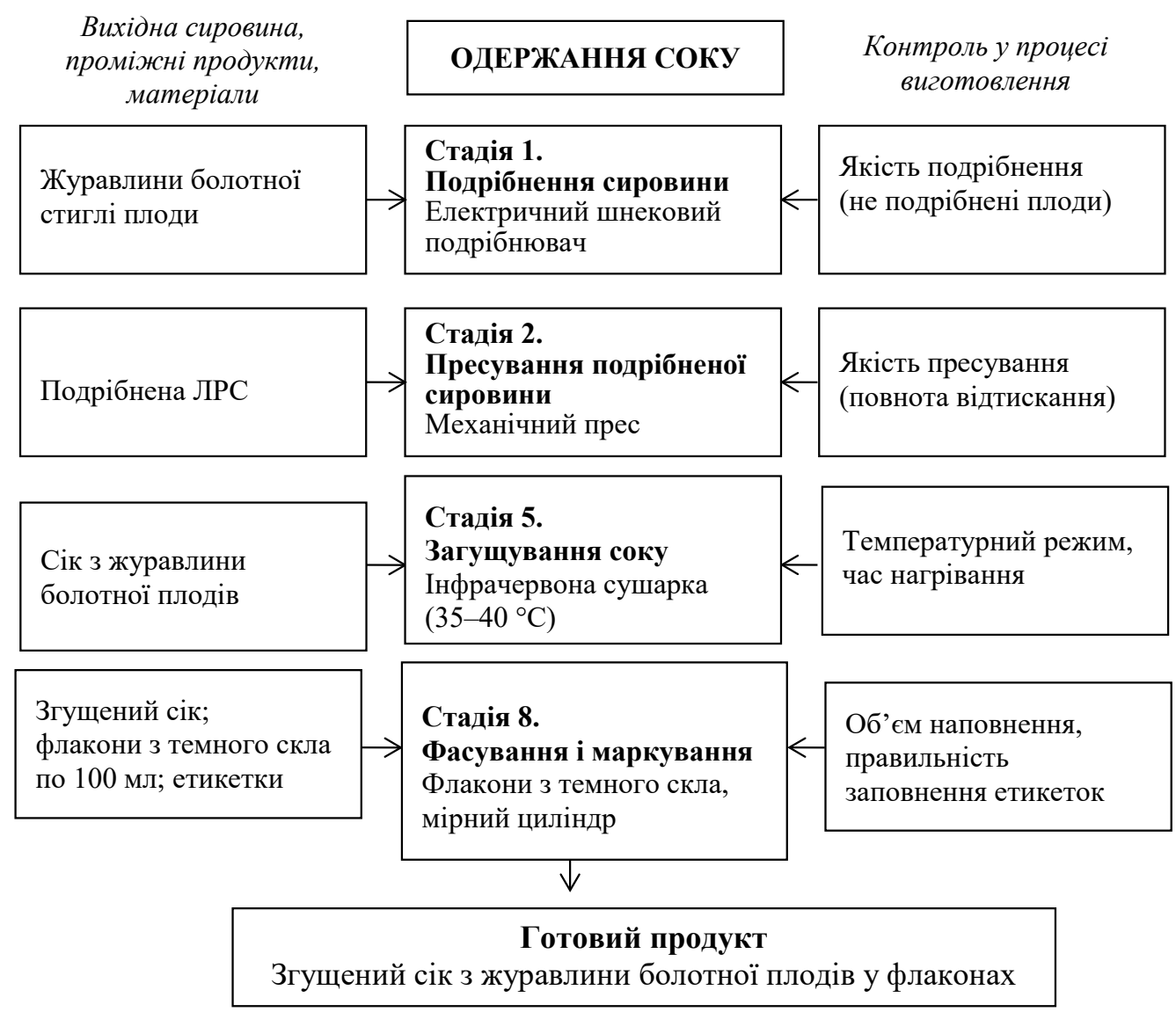

Рис. Технологічна схема одержання згущеного соку з журавлини болотної плодів.

ВИСНОВКИ. 1. Обґрунтовано оптимальний метод одержання свіжого соку з журавлини болотної плодів та визначено такі його критерії якості, як: зовнішній вигляд, рН від 2,46 до 2,5, ідентифрікація методами тонкошарової хроматограсрії, кольоровими реакціями, кількісне визначення методами титриметрії та УФ-спектрофотометрії (органічні кислоти - не менше 0,78 \%, поліфеноли - не менше 1,8\%, таніни - не менше 0,39 \%, проантоціанідини - не менше $0,33 \%)$

\section{СПИСОК ЛІТЕРАТУРИ}

1. Настанова Європейської асоціації урологів із лікування інсрекцій сечових шляхів (EAU, 2012/2013).

2. Cavanagh H. M. A. Antibacterial activity of berry fruits used for culinary purposes / H. M. A. Cavanagh, M. Hipwell, J. M. Wilkinson // J. Med. Food. - 2003. -6, No. 1. - P. 57-61.

3. Яцюк К. М. Вивчення антимікробної дії згущеного соку з плодів журавлини болотної (Vaccinium oxycoccos L.) / К. М. Яцюк, М. І. Федоровська, Р. В. Ку-
2. При одержанні згущеного соку з журавлини болотної плодів встановлено, що оптимальним методом загущування $€$ інфррачервоне сушіння при $35-40^{\circ} \mathrm{C}$ до $30 \%$ від початкової маси.

3. Визначено основні показники якості згущеного соку з журавлини болотної плодів, а саме: опис, рН від 2,46 до 2,5, кількісний вміст (органічні кислоти - не менше 2,37 \%, поліфеноли - не менше 5,37\%, таніни - не менше 1,06 \%, проантоціанідини - не менше 0,95 \%).

4. Розроблено технологічну схему одержання згущеного соку з журавлини болотної плодів.

цик // Фармац. журн. - 2017. - № 1. - C. 84-92.

4. Guay D. R. Cranberry and urinary tract infections / D. R. Guay // Drugs. - 2009. - 69, No. 7. - P. 775-807. doi: 10.2165/00003495-200969070-00002

5 . Effects of cranberry extracts on growth and biofilm production of Escherichia coli and Staphylococcus species / K. L. LaPlante, S. A. Sarkisian, S. Woodmansee [et al.] // Phytother. Res. - 2012. - 26, No. 9. - P. 13711374. doi: 10.1002/ptr.4592 
6. In vivo consumption of cranberry exerts ex vivo antiadhesive activity against fimH-dominated uropathogenic Escherichia coli: A combined in vivo, ex vivo, and in vitro study of an extract from Vaccinium macrocarpon / N. Rafsanjany, J. Senker, S. Brandt [et al.] // J. Agric. Food Chem. - 2015. - 63, No. 40. - P. 8804-8818. doi: 10.1021/acs.jafc.5b03030

7. Солодовниченко Н. М. Лікарська рослинна сировина та фрітопрепарати : посіб. з фрармакогнозії 3 основами біохімії лікарських рослин / Н. М. Солодовниченко, М. С. Журавльов, В. М. Ковальов. - Х. : Вид-во НФАУ “Золоті сторінки", 2001. - 408 с.

8. Державна Фармакопея України / Державне підприємство "Український науковий фрармакопейний центр якості лікарських засобів". - 2-ге вид. - Харків : Державне підприємство "Український науковий фрармакопейний центр якості лікарських засобів", 2015. T. 1. -1128 c.

\section{REFERENCES}

1. Nastanova Yevropeyskoi asotsiatsii urolohiv iz likuvannia infektsii sechovykh shliakhiv [The European Association of Urology Guideline about urinary tract infections treatment]. EAU, 2012,2013 [in Ukrainian].

2. Cavanagh, H.M.A., Hipwell, M., \& Wilkinson, J.M. (2003) Antibacterial activity of berry fruits used for culinary purposes. J. Med. Food., 6 (1), 57-61.

3. Yatsiuk, K.M., Fedorovska M.I. \& Kutsyk R.V (2017). Vyvchennia antymikrobnoi dii zhushchenoho soku z plodiv zhuravlyny bolotnoi (Vaccinium oxycoccos L.) [The investigation of the cranberry concentrated juice antimicrobial activity]. Farmatsevtychnyi zhurnal - Pharmaceutical Journal, 1, 84-92 [in Ukrainian].

4. Guay, D.R. (2009) Cranberry and urinary tract infections. Drugs, 69 (7), 775-807. doi: 10.2165/00003495200969070-00002

5. LaPlante, K.L., Sarkisian, S.A., Woodmansee, S., Rowley, D.C., \& Seeram, N.P. (2012). Effects of cranberry extracts on growth and biofilm production of Escherichia coli and Staphylococcus species. Phytother. Res., 26 (9), 1371-1374. doi: 10.1002/ptr.4592
6. Rafsanjany, N., Senker, J., Brandt, S., Dobrindt, U. \& Hensel, A. (2015). In vivo consumption of cranberry exerts ex vivo antiadhesive activity against FimH-dominated uropathogenic Escherichia coli: Acombined in vivo, ex vivo, and in vitro study of an extract from Vaccinium macrocarpon. J. Agric. Food Chem., 63 (40), 8804-8818. doi: 10.1021/acs.jafc.5b03030

7. Solodovnychenko, N.M., Zhuravlov, M.S. \& Kovalov, V.M. (2001). Likarska roslynna syrovyna ta fitopreparaty: posib. z farmakohnozii z osnovamy biokhimii likarskykh roslyn [Medicinal plants and herbal medicines, training manual. Pharmacognosy with basic biochemistry of medicinal plants]. Kharkiv: Vyd-vo NFAU Zoloti storinky [in Ukrainian].

8. (2015). Derzhavna Farmakopeia Ukrainy: $v 3 t$. Derzhavne pidpryiemstvo "Ukrainskyi naukovyi farmakopeinyi tsentr yakosti likarskykh zasobiv" [State Pharmacopeia of Ukraine: in 3 vol. / State Enterprise "Ukrainian Scientific Pharmacopoeial Centre of Medicinal drugs Quality]. Kharkiv: Derzhavne pidpryiemstvo "Ukrainskyi naukovyi farmakopeinyi tsentr yakosti likarskykh zasobiv" [in Ukrainian].

К. М. Яцюк ${ }^{1}$ М. И. Федоровская ${ }^{1}$, С. М. Марчишин ${ }^{2}$, Л. И. Будняк², Л. В. Слободянюк ${ }^{2}$ ИВАНО-ФРАНКОВСКИЙ НАЦИОНАЛЬНЫЙ МЕДИЦИНСКИЙ УНИВЕРСИТЕТ ТЕРНОПОЛЬСКИЙ ГОСУДАРСТВЕННЫЙ МЕДИЦИНСКИЙ УНИВЕРСИТЕТ ИМЕНИ И. Я. ГОРБАЧЕВСКОГО

\section{ПОЛУЧЕНИЕ И СТАНДАРТИЗАЦИЯ СГУЩЕННОГО СОКА ИЗ КЛЮКВЫ БОЛОТНОЙ ПЛОДОВ}

\section{Резюме}

Вступление. Ценным сырьем для разработки фритопрепаратов являются клюквы болотной плоды, которые применяют при лечении инфекций мочевыводящей системы, простудных и стоматологических заболеваний. Биологически активные вещества, которые содержатся в этом сырье, способны проявлять антимикробные свойства по отношению к главным уропатогенным итаммам микроорганизмов. При разработке твердых лекарственных фрорм для применения в урологии перспективным является получение сгущенного сока из клюквы болотной плодов.

Цель исследования - разработать технологию получения и осуществить стандартизацию сгущенного сока из клюквы болотной плодов. 
Методы исследования. Свежеполученный и сгущенный сок из клюквы болотной плодов подвергали анализу по таким показателям, как: описание, $\mathrm{pH}$, сухой остаток (свежий сок), идентификация и количественное определение основных групп биологически активных веществ.

Результаты и обсуждение. В результате проведенных исследований разработано оптимальную технологию получения сгущенного сока из клюквы болотной плодов. Для свежеполученного и сгущенного сока определено основные показатели качества.

Выводы. Обосновано оптимальный метод получения свежего сока из клюквы болотной плодов и определено такие его критерии качества, как: внешний вид, рH от 2,46 до 2,5, идентификация методами тонкослойной хроматографрии, цветными реакциями, количественное определение методами титриметрии и УФ-спектрофотометрии (органические кислоты - не менее 0,78 \%, полифенолы - не менее 1,8 \%, танины - не менее 0,39 \%, проантоцианидины - не менее 0,33 \%). При получении сгущенного сока из клюквы болотной плодов установлено, что оптимальным методом загущения является инфракрасная сушка при 35-40 ㄷ до 30 \% от начальной массы. Определено основные показатели качества сгущенного сока из клюквы болотной плодов, а именно: описание, $\mathrm{pH}$ om 2,46 до 2,5, количественное содержание (органические кислоты - не менее 2,37 \%, полифренолы - не менее 5,37 \%, танины - не менее 1,06 \%, проантоцианидины - не менее 0,95 \%). Разработано технологическую схему получения сгущенного сока из клюквы болотной плодов.

КЛЮЧЕВЫЕ СЛОВА: клюква болотная; сгущенный сок; биологически активные вещества; спектрофротометрия; технология сока.

K. M. Yatsyuk ${ }^{1}$, M. I. Fedorovska ${ }^{1}$, S. M. Marchyshyn², L. I. Budniak², L. V. Slobodianiuk ${ }^{2}$ IVANO-FRANKIVSK NATIONAL MEDICAL UNIVERSITY ${ }^{1}$ I. HORBACHEVSKY TERNOPIL STATE MEDICAL UNIVERSITY²

\section{OBTAINING AND STANDARDIZATION OF CONDENSED JUICE FROM CRANBERRIES MARSH FRUITS}

\section{Summary}

Introduction. Cranberries marsh fruits is a valuable raw material for the development of phyto preparations, which are used in the treatment of urinary tract infections (UTI), colds and dental diseases. Biologically active substances (BAS) contained in this raw material and can exhibit antimicrobial properties to the major uropathogenic strains of microorganisms. Obtaining condensed juice from Cranberries marsh fruits is promising, when developing solid dosage forms for use in urology.

The aim of the study - to develop a technology obtaining and standardize condensed juice from Cranberries marsh fruits.

Research Methods. Freshly prepared and concentrated juice from Cranberries marsh fruits was analyzed by the following parameters: description, $\mathrm{pH}$, dry residue (fresh juice), identification and quantitative determination of the main groups of biologically active substances.

Results and Discussion. The optimum technology of reception of condensed juice from Cranberries marsh fruits was developed during conducted researches. The basic quality indicators are determined for the fresh condensed juice.

Conclusions. The optimum method for obtaining fresh juice from Cranberries marsh fruits is substantiated. Its quality criteria are defined: appearance, $\mathrm{pH}$ from 2.46 to 2.5, identification by Liquid chromatography-mass spectometry, color reactions and quantitative determination by titrimetry and ultraviolet spectrophotometry: organic acids - not less than $0.78 \%$, polyphenols - not less than $1.8 \%$, tannins - not less than $0.39 \%$, proanthocyanidine - not less than $0.33 \%$. In obtaining concentrated juice from Cranberries marsh fruits, it is found that the optimal method of thickening is infra-red drying at $35-40{ }^{\circ} \mathrm{C}$ up to $30 \%$ of the initial mass. The main indicators of quality of condensed juice from Cranberries marsh fruits are determined as description, $\mathrm{pH} 2.46$ to 2.5 and quantitative content of organic acids - not less than $2.37 \%$, polyphenols - not less than $5.37 \%$, tannins - not less than $1.06 \%$, proanthocyanidines not less than $0.95 \%$. The technological scheme of obtaining condensed juice from Cranberries marsh fruits was developed.

KEY WORDS: cranberry marsh; condensed juice; biologically active substances; spectrophotometry; juice technology.

Отримано 25.04.19

Адреса для листування: С. М. Марчишин, Тернопільський державний медичний університет імені І. Я. Горбачевського, майдан Волі, 1, Тернопіль, 46001, Україна, e-mail: marchyshyn@tdmu.edu.ua. 